\section{Perception of Trust Levels in Organizations Based upon Opinions of Polish and Ukrainian Employees - Results of a Pilot Study}

\author{
Piotr Kowalczyk \\ Department of Management Information Systems \\ Maria Curie-Sktodorwska University, Poland \\ piotr.korwalczyk@poczta.umcs.lublin.pl \\ Magdalena Oronowicz \\ Management Science, doctoral studies \\ Maria Curie-Sktodoreska University, Poland \\ magda.oronowicz@gmail.com \\ Sylwia Samuła \\ Management Science, doctoral studies \\ Maria Curie-Sktodoreska University, Poland \\ sylwiagebicz@wp.pl
}

Perception of Trust Levels in Organizations Based upon Opinions of Polish and Ukrainian Employees - Results of a Pilot Study

\footnotetext{
Abstract

Objective - Due to the increasing share of Ukrainians in the Polish labor market, an analysis concerning the evaluation of trust levels exhibited by Polish and Ukrainian employees of Polish organizations was conducted. The assessment serves to merely outline the issue. Further studies on a more representative sample ought to be continued.

Approach - The paper is based upon the review of literature regarding the scope of social capital and results of a pilot study conducted with the use of a questionnaire. The pilot encompassed 84 respondents. The questionnaire was developed on the basis of tools applied by other authors. The study encompassed Polish and Ukrainian employees due to the increasing share of the latter in the Polish labor market.

Results - Results indicate that the employees, regardless of their nationality, manifest a rather high trust level. Respondents of both nationalities believe that their colleagues are friendly and eagerly share knowledge. The results indicate that they are aware of their duties and need not be controlled and overseen. However, they openly admit that their organizations do not shy from gossip and criticism, which begs for more scrutiny.

Limitations / research implications - The limitation of the present paper can be seen in the non-representative character of the sample. Moreover, it would be beneficial to expand the questionnaire in order to gain more insight into the issue.
}

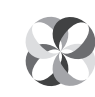

synergia

International Journal of Synergy and Research Vol. 7, 2018 pp. $81-95$ 
IJSR 7

Originality / value - Despite the limitations, the results are interesting due to the increasing number of Ukrainian employees in Polish organizations.

Paper type - Empirical.

Keywords - social capital, trust, types of trust, organizational success

\section{Introduction}

Polish labor market is open to people coming from Ukraine. They are satisfied with working in Poland. However, studies indicate that $59 \%$ of Ukrainians employed in Poland declared they will pursue employment in Germany if Polish immigration policy does not change (Horwat, 2017). Therefore, it is critical that Ukrainians are treated well in the organizational environment. In such a context, diversity management and inclusion management in Polish organizations gain significance (Rakowska, 2018; Shore et al., 2018). As a consequence, the need for studies enabling foreign employees to be retained in Poland arises.

The concept of social capital is strongly associated with the organizational climate. The capital constitutes one of the elements of intellectual capital and exerts an impact upon its development in the organization. It contributes to improved work effectiveness and stimulates cooperation and learning processes (Hughes et al., 2014; Kuranchie and Addo, 2017; Liu, 2018). Initially, it was sociologists who were chiefly interested in social capital. Currently, various fields have begun to explore the concept.

Trust constitutes an element of social capital. It has also become a research object. Trust is linked with companies' success and employee engagement. It has also become an inseparable element of well-developing organizations which, owing to their social capital, became "indestructible".

On the other hand, when observing changes occurring on the Polish labor market, and the growing share of Ukrainian employees among these, it seems valid to examine the perception of the level of trust among this group of workers and compare it with the perception of trust manifested by Polish employees. In particular, the issue seems compelling due to the fact that the data of the European Social Survey (ESS) suggests Poles are definitely less confident than other European nations (European Social Survey is an international research project implemented every two years. Twenty-two European states participate) (Archiwum Danych Społecznych).

\section{The concept of social capital}

The definition offered by Putnam (1995, after: Sierocińska, 2011, p. 70) may be considered as one of the first fundamental definitions of social capital. Putnam described social capital as a collection of features of social organizations, networks of individuals or households, and norms and values associated with these, which form external outcomes for the general community. A similar definition was proposed by Fukuyama who defined social capital as a "collection of informal values and ethical norms shared by the members of a specific group, which enables them to cooperate successfully". Fukuyama argued that only a limited number of people, instead of all members of a particular community, will agree with the specific norms and values (Fukuyama, 
2003). Coleman offered a different approach to the issue (Sierocińska, 2011, p. 70). He believes that social capital is a feature of small groups exhibiting strong relations. Groups are developed in order for people to realize their own objectives. Social capital emerges along with the development of human interrelations. Both old and new group members may benefit from it. In this case, the capital does not stem from conscious actions of people, but from strong relations emerging in the group (Sierocińska, 2011, p. 70). Bourdieu approached the issue in yet another way. He defined the capital as "individual investments in the network of social relations". In addition, it is believed that social capital constitutes a private, and not public, good, and that it is a significant element of the social position of a particular individual (Bourdieu, 1986, 1993, after: Czapiński, 2008, p. 8).

When defining social capital, three levels which are frequently featured in the literature of the subject, are noteworthy (Pawłowska, 2012, pp. 88-89):

- micro level - it is a transitory form between human and social capital. Elements characteristic for both types of capital are present. On this level, social capital is associated with the research contribution of Putman,

- mezo level - the analysis of capital is associated with Coleman who argues that the capability of forming groups in order to achieve a specific objective constitutes a significant element of human potential,

- macro level - this level of capital encompasses social and political environments which shape structures and enable norms to be developed. Scholars believe that government institutions exert a considerable impact upon the development of mutual relations by the rules of law or the scope of powers/rights.

As far as organizations are concerned, social capital is developed by their various features which stimulate cooperation. The features include networks facilitating the exchange of information, but also concluding contracts, establishment of norms, cooperation and trust levels. The ability to form groups constitutes a vital element of social capital in the organization. Such a formation is based upon trust and is understood as the primary and measurable economic value. According to Szczepański, social capital in the organization constitutes a force driving cooperation which teaches compromise and dialogue and is characterized by truthfulness and credibility (Szczepański after: Wróbel, 2010, pp. 132-133).

\section{Dimensions of social capital}

According to Putnam's and Bourdieu's theories two dimensions of social capital are distinguished (Zarycki, 2008):

- bonding capital - it is associated with small communities and families. It is characterized by the fact that group members know one another and their mutual trust is frequently based upon blood ties,

- $\quad$ bridging capital - it pertains to larger communities and formal organizations, i.e. groups where members do not know one another personally and are not joined by direct contacts. In this case, one ought to be open to new acquaintances and be tolerant as far as principles of the particular community are concerned.

Other scholars examining social capital believe that it constitutes a three-dimensional structure which consists of the following dimensions (Wróbel, 2010):
Perception of Trust Levels in Organizations Based upon Opinions of Polish and Ukrainian Employees - Results of a Pilot Study 
IJSR 7
- cognitive, which encompasses:

o a universal code, e.g. type of language, which is a vital element of building relations,

o relations linking community members. These facilitate the acquisition of goods, e.g. knowledge,

- relational, which encompasses:

o trust - a belief that a person's behavior will be in accord with our principles,

o norms setting the level of understanding in a particular social organization,

o expectations and duties, i.e. an obligation to undertake joint initiatives in the future. This stems from universally accepted norms and manifests as an expectation resulting from the relation,

o identification - it is a constituting element of the process where particular characteristics of individuals are used for the benefit of the whole group,

- structural, which encompasses:

o bonds developed in a network system,

o development of configurations of these networks,

o organizational adequacy.

On the one hand, the compliance with norms which constitute social capital may stimulate the involvement with actions for the public good and local communities. However, on the other hand, it may limit economic activity. Therefore, caring for social and economic aspects simultaneously is critical (Wróbel, 2010).

\section{What is trust?}

Trust has been a popular concept in the field of management. However, managers have only recently begun to recognize its value (Tantardini and Kroll, 2015). Sztompka defines trust as "an expectation of beneficial actions of partners in the interaction or social relations" (Sztompka, 2005). In accordance with the principles of daily life sociology, trust is present in all elements of our lives (Mularska-Kucharek, 2011). The literature on the subject frequently features a general definition of trust as a culture of trust. The culture developed in a particular community is beneficial because their initiatives are more open, innovative and spontaneous. In addition, the culture exerts a positive impact upon structural determinants, which contributes to the consolidation and expansion of trust in the community (Czajkowska 2008).

In organizations, trust emerges from the way managers refer to their subordinates. Credibility and acceptance form the base for trust. The more credible the manager, the greater trust their employees exhibit, which translates into higher performance. Acceptance revolves around treating oneself and others seriously, which denotes acceptance of faults, merits and peculiarities. However, this is not unanimous with accepting the lack of employees' scrupulousness. Intervening in employees' actions ought to entail understanding their autonomy (Królik, 2015). It is noteworthy that trust has considerable significance in superior-subordinate relationships due to the fact that employees are more engaged in their duties when the relationship with the superior is positive (Lewicka and Krot, 2014). Trust is closely linked with values present in a particular organization. It also generates principles and norms present in it. Trust emerges on several levels. Organizational trust is strictly connected with organizational culture. It pertains to interpersonal relations, 
norms and customs in the organization. As a consequence, leadership and a system for monitoring is a crucial on this level. Undeniably, relations among individual employees are also significant as far as the development of trust is concerned. Research results prove that this level of trust exerts an impact upon knowledge sharing and coordination of processes in the organization (Gross-Gołacka, 2017, p. 83).

Research also proves that there exists a relationship between the level of trust and effectiveness. Employees who are satisfied with their work manifest a high level of trust (Ozyilmaz et al., 2018).

\section{Sources and types of trust}

Trust is an element associated with several aspects of our lives. It constitutes one of the fundamental interpersonal relations, both among family members and social groups. It is also of value in organizations on various levels. The following trust relationships may be enumerated: employee-employee, subordinate-superior, superior-subordinate. Trust constitutes a dimension of social capital developed over a long period of time. When discussing trust, apart from its essence, indicating its sources (determinants of its development) and types of trust is worthwhile.

The literature indicates 3 fundamental sources of trust:

1. Historical legacy

2. Structural context

3. Subject-related instruments

Historical legacy is the so-called background variable (Czajkowska, 2008). It stems from the past of a particular community. It constitutes a general tendency for expressing trust towards various objects (Sztompka, 2005). Human tendencies for placing one's trust in others stem from historical legacy. The legacy also points to specific experiences from the past which may bear suspicions or fill with hope. Based upon the legacy, an individual may thus make a swift decision whether they can place their trust in a particular object. Due to its essence, historical trust in non-modifiable. Therefore, certain innate predispositions towards trust and experiences of a community cannot be changed. Moreover, the existence of multiculturality ought to be discussed. It is characteristic for modern organizations (Bjerke, 2004). Cultural diversity has been problematic for managing diversified personnel. The development of trust culture has proven helpful as far as managing cultural diversity is concerned.

The next source of trust is the cultural context which constitutes an independent variable and is determined by the following (Grudzewski et al., 2007):

- normative stability - it exerts an impact upon the emergence of predictability and order, which ultimately, offer the feeling of security. In addition, normative stability acknowledges the existence of a system of social rules which indicate methods for achieving an objective in a clear way,

- $\quad$ stability of social order - it indicates a relative permanence and invariability of organizational structures, social order and technical environment of daily life. In addition, any change in these elements is slow and minute,

- transparency of a social organization - it is based upon a premise that the familiar stimulates trust. Organizations which strive for their activities to be based upon trust must describe the composition, principles and competences of their structures to
Perception of Trust Levels in Organizations Based upon Opinions of Polish and Ukrainian Employees - Results of a Pilot Study 
IJSR 7
Table 1.

Types of trust their stakeholders. In addition, the ease of understanding, transparency and control of the achieved results contribute to the increase of trust and security,

- subordination of authorities to legal regulations - the development of trust is facilitated by the following factors: supervision and control over officials, established procedural frameworks, the ability to appeal to higher authorities. It has also been recognized that suitable content, fairness and legitimacy of decisions made by authorities stimulate the increase of trust,

- consistent realization of rights and enforcement of duties - this element is associated with the existence and appropriate operation of independent institutions (e.g. courts, tribunals) or agendas enforcing the realization of duties (prosecutors, police) one can appeal to in order to protect endangered rights. The operation of these institutions and agendas limits fear and anxiety associated with abuse, crime or fraud, which, ultimately, leads to the emergence of the culture of trust.

The third determinant of the emergence of trust is subject-related instruments. It is defined as an intervening variable. The instrument constitutes a certain resource of measures for human activity (Czajkowska, 2008). The culture of trust emerges due to proper reactions of community members to elements of structural context. It ought to be highlighted that various features of character influence cognition and evoke different reactions of people to the same situations. Subject-related instruments are composed of two chief groups of factors:

1. Personality traits - these exert a positive impact upon the development of trust, which constitutes a natural element of social orientation. Personality traits include optimism, high aspirations, activism, stimulation of success and focus upon the future.

2. Social capital resources - resources an individual possesses which foster a greater openness, security, and contribute to the development of trust culture. These resources include: education, family support, acquaintances, contacts, properties, possessions, health condition, readiness for risk, and religiousness. It is noteworthy that these elements constitute a theoretical model. In practice, it is virtually impossible that each of these emerges.

Trust builds over the course of years. One error is enough to lose trust and become distrustful. The loss of trust brings pain, disappointment and the feeling of loss. It introduces chaos in both professional and personal relations (Paliszkiewicz, 2014). The loss of trust exerts an impact upon various aspects of the organization's operation. The cost is usually high and depends upon the type of trust which was destroyed. As far as the types of trust are concerned, six fundamental types can be distinguished (Table 1).

\begin{tabular}{ll}
\hline \multicolumn{1}{c}{ Type of trust } & \multicolumn{1}{c}{ Description } \\
\hline Personal & Trust for a particular person \\
\hline Position-related & Trust for a particular social group, position, profession \\
\hline Commercial & Trust for products, goods, companies, brands \\
\hline Technological & Trust for various types of technological systems (IT, energy, communication) \\
\hline Institutional & $\begin{array}{l}\text { Trust for complex organizations engaging anonymous members (e.g. universities, stock exchange, } \\
\text { banks) }\end{array}$ \\
\hline Systemic & Trust for the whole social system and its members; the most abstract type of trust \\
\hline
\end{tabular}

Source: Own study on the basis of Nowakowski (2008, p. 215). 
The literature on the subject indicates the existence of trust on three main levels:

1. Personalized - trust towards people we know. This is clear and obvious. However, it ought to be noted that trust towards close ones and the specific value of family may foster optimism, openness to others, inclination towards risk-taking in one community, but limit contacts with and trust for strangers, and become a syndrome of a general lack of trust.

2. Social - trust towards strangers. It is based upon the premise that life in a divided society is easier and happier provided a generalized trust is present. People become distrustful only in specific situations (e.g. when a plumber decides to repair breaks in a car).

3. Institutional - trust is based primarily upon indirect experience and information on institutions and political leaders. Trust for public institutions reduces costs of introducing legal regulations, but also creates collective actions. Low trust for public institutions endangers the stability of the whole democratic system (Nowakowski, 2008). In the $21^{\text {st }}$ century, trust is one of the chief aspects of social capital. It facilitates the development of a suitable organizational culture, fosters a positive attitude of both the management cadre and personnel towards their colleagues and organization, and consolidates interpersonal relations. Even though trust may be difficult to gain and requires constant care, it contributes to the joint success of the company.

Due to the fact that social capital and the trust level associated with it are correlated with several attitudes and employee behavior, e.g. job involvement, intent for leaving the organization, a premise was made that it is worthwhile to examine trust levels of Polish and Ukrainian employees (Peltokorpi et al., 2015; Lin and Liu, 2017; Andresen et al., 2017).

\section{Results of the study pertaining to trust in Polish companies}

The study was conducted in January 2018. The assessment was based upon a survey questionnaire. Questions were developed on the basis of the paper titled "Rola zaufania w zarządzaniu przedsiębiorstwami" ("The role of trust in company management") by Paliszkiewicz (2014).

The main objective of the study was to evaluate the expansion of trust levels of young Poles and Ukrainians currently or previously employed in Polish organizations. The questionnaire consisted of 7 personal details questions and 6 questions pertaining to two areas:

1. Focus upon the development of trust.

2. Focus of the organization upon the development of trust-based culture.

Three statements were allocated to each of the areas (Table 2). Respondents were requested to express their opinion by means of a 1-5 Likert-type scale with the following designations:

$$
\begin{aligned}
& 1 \text { - "strongly disagree" } \\
& 2 \text { - "disagree" } \\
& 3 \text { - "neither agree nor disagree" } \\
& 4 \text { - "agree" } \\
& 5 \text { - "strongly agree" }
\end{aligned}
$$

Perception of Trust Levels in Organizations Based upon Opinions of Polish and Ukrainian Employees - Results of a Pilot Study 
IJSR 7

Table 2.

Statements featured in the survey questionnaire
When analyzing the individual statements, scores for 1 and 2, and 4 and 5 were added up.

\begin{tabular}{|c|c|}
\hline One should not trust others until one becomes familiar with them & \multirow{3}{*}{ - Focus upon the development of trust } \\
\hline Employees in your organization wish others well & \\
\hline $\begin{array}{l}\text { Employees in your organization feel responsible for their duties and need } \\
\text { not be overseen }\end{array}$ & \\
\hline People eagerly share knowledge & \multirow{3}{*}{$\begin{array}{l}\text { Focus of the organization upon the } \\
\text { development of trust-based culture }\end{array}$} \\
\hline People avoid gossip and unfair criticism of others & \\
\hline $\begin{array}{l}\text { Your organization is interested in employees being aware of why } \\
\text { a particular decision is made }\end{array}$ & \\
\hline
\end{tabular}

Source: Authors' own study on the basis of Paliszkiewicz (2014, pp. 412-414).

The questionnaire addressed a purposively selected sample consisting of Poles and Ukrainians aged 18-30 currently or previously employed in Poland. The questionnaire was posted on social media (Facebook). Ultimately, the study encompassed 84 respondents -52 women (62\%) and 32 men (38\%) aged 18-30. Forty-nine respondents $(57 \%)$ were Polish and 35 (43\%) Ukrainian. Ukrainians have resided in Poland for between 1 and 9 years. As far as the specific period of residence is concerned, $36 \%$ of Ukrainians have lived in Poland for 1-3 years, $45 \%$ - from 4 to 5 years, and 19\% - from 6 to 9 years.

With regard to the employment structure, $56 \%$ of respondents have been employed in Polish private companies, $35 \%$ in international corporations, and the remaining $9 \%$ were self-employed or worked in public administration and state-owned companies and government organizations.

The majority of respondents (58\%) have been employed for less than a year, 38\% for 1 to 5 years, and 4\% for 6 to 10 years. Approximately half of respondents $(45 \%)$ worked under a fixed period employment contract, $37 \%$ - under a commission contract, $17 \%$ - under a permanent employment contract, and 1\% - under a specific task contract.

Taking the 5-point scale into consideration, when analyzing research results, the results were divided into three categories and scores were added up - negative scores (1 - "strongly disagree"; 2 - "disagree"), positive scores (4 - "agree" and 5 - "strongly agree") and neutral.

When evaluating the results, it may be observed that they are relatively high, especially with regard to both types of focus specified in the questionnaire, i.e. focus of the manager upon developing trust, and focus of the company upon developing trustbased culture.

The first statement pertained to trust towards new acquaintances. Both Poles (73\%) and Ukrainians (54\%) employed in their organizations agree that people ought not to be trusted until one becomes familiar with them (results refer to people selecting answers 4 and 5). Such results prove that Poles manifest slightly lower trust than Ukrainians. Merely $8 \%$ of Polish and $20 \%$ of Ukrainian employees disagree with the statement (results refer to people who selected answers 1 - "strongly disagree" and 2 - "disagree"). Those selecting answer 3 ("neither agree nor disagree") encompassed 19\% of Poles and $26 \%$ of Ukrainians. When assessing the statement with regard to sex, it was observed that men (72\%) exhibit a slightly higher mistrust towards new acquaintances. Women 
manifest a relatively lower mistrust (62\%) towards them. Merely $6 \%$ of men and $17 \%$ of women disagree with the examined statement. The analysis of answers to the statement with regard to nationality is outlined in Figure 1.

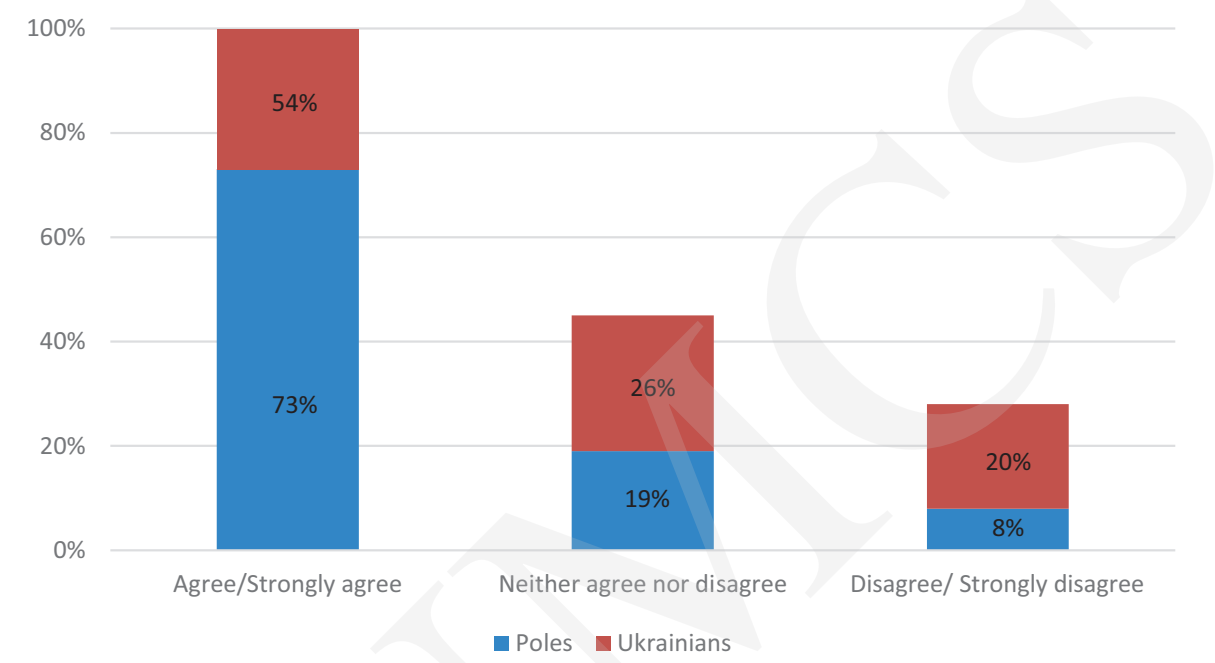

Source: Authors' own study.

The lack of trust does not facilitate the development of trust by managers and indicates the fact that it is missing as far as new acquaintances are concerned. This may bear a series of consequences, e.g. the newly employed may feel alien in the organization, which, in turn, exerts an impact upon the quality of their work.

The next statement pertained to friendliness of colleagues in the organization. The results of the study are very satisfactory in this respect. The majority of respondents indicate that coworkers are friendly towards one another.

As far as respondents' nationality is concerned, no significant differences of opinion were observed. Poles (60\%) and Ukrainians (53\%) believe that employees of their organization wish them well. Merely $15 \%$ of Poles and $14 \%$ of Ukrainians indicate the lack of friendliness at their workplace. $25 \%$ of Poles and $33 \%$ of Ukrainians neither agreed nor disagreed. As far as respondents' sex is concerned, women exhibited more friendliness $(63 \%)$. On the other hand, $47 \%$ of men believe their colleagues are friendly and $38 \%$ disagree with the statement. $13 \%$ of women and $17 \%$ of men neither agree nor disagree. Undeniably, friendliness constitutes a vital aspect of any organization because it influences the atmosphere within. Both managers and employees themselves ought to strive to maintain proper relations. Pleasant work atmosphere exerts a positive impact upon work attitude. Employees are eager to come to work, thus they conduct their duties with a greater involvement and scrupulousness.

The third statement concerning the managers' focus upon developing trust pertained to the feeling of employees' responsibility for duties they were to carry out without being overseen. Both Poles and Ukrainians (59\%) believe employees in their companies are aware of their responsibilities and need not be monitored and controlled by their
Perception of Trust Levels in Organizations Based upon Opinions of Polish and Ukrainian Employees - Results of a Pilot Study

Figure 1. Results pertaining to statement No. 1 with regard to respondents' nationality: One should not trust others until one becomes familiar with them 


\section{IJSR}

7

superiors. $30 \%$ of Poles and $17 \%$ of Ukrainians neither agree nor disagree. $13 \%$ of Poles believe that employees require being monitored by managers because they neglect their duties. Similarly, $22 \%$ of Ukrainians are of such an opinion. As far as respondents' sex is concerned, $67 \%$ of women and $44 \%$ of men believe that employees feel responsible for their duties and need not be overseen. The contrary opinion was expressed by $15 \%$ of women and $22 \%$ of men. $17 \%$ of women and $34 \%$ of men neither agreed nor disagreed.

Supervision of employees who properly conduct their work has frequently proven to exert a negative impact upon work atmosphere. Employees have no freedom to act and feel their superiors do not trust them. Oversight ought to be placed upon those who neglect their duties and do not express awareness of being responsible for their work. It is noteworthy that managers who supervise employees apply constructive criticism to motivate employees to work better.

The fourth statement is associated with the company's focus upon developing trustbased culture, and pertains to the willingness to share knowledge in the organization. $79 \%$ of Poles and $62 \%$ of Ukrainians indicate that their colleagues are willing to share knowledge. This disproportion seems significant and may denote that only Poles are more willing to share knowledge with others. Merely $8 \%$ of Poles and $19 \%$ of Ukrainians disagree with the statement. $13 \%$ of Poles and $19 \%$ of Ukrainians neither agree nor disagree. $73 \%$ of women and $69 \%$ of men believe that employees in their organization are very willing to share knowledge. $15 \%$ of women and $16 \%$ of men disagreed. $12 \%$ of women and $16 \%$ of men neither agreed nor disagreed. The detailed analysis of the statement with regard to respondents' nationality is outlined in Figure 2.

Figure 2.

Results pertaining to statement No. 4 with regard to respondents' nationality: People eagerly share knowledge

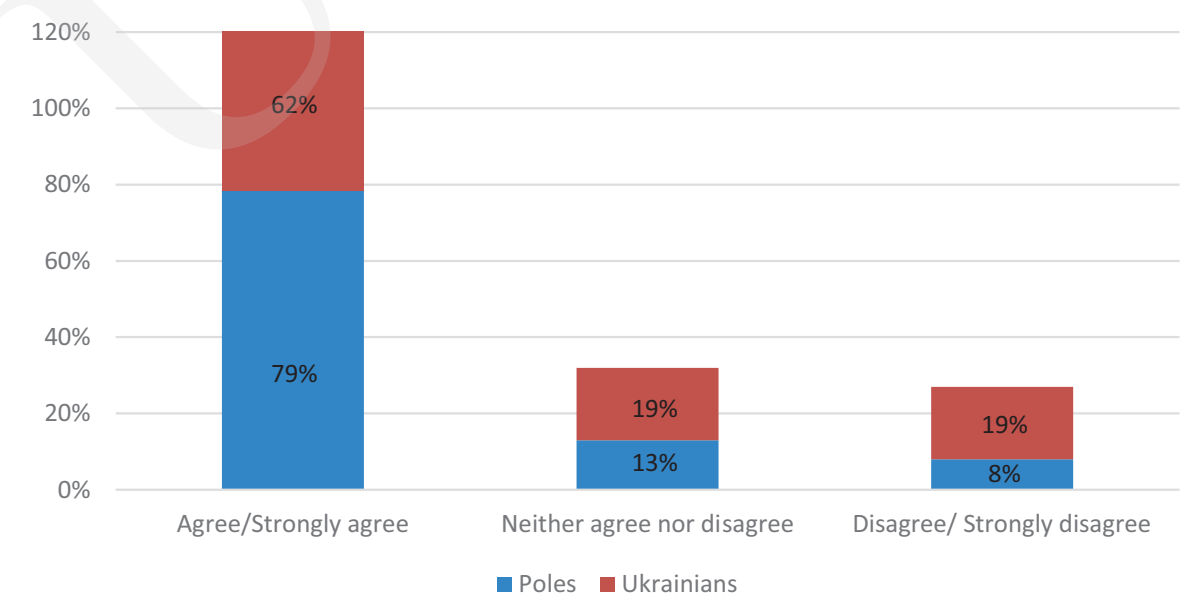

Source: Authors' own study.

Knowledge sharing in knowledge-based economy has become one of the chief processes of every organization. Frequently, the transfer of vital observations and information facilitates work. Recurring faults may be eliminated more swiftly and with greater precision.

The next statement pertained to attitudes of employees towards gossip and unfair criticism. Unfortunately, the results are not as optimistic as those pertaining to the previous 
statements. 54\% of Poles and 33\% of Ukrainians indicate that people in their organizations do not avoid gossip and criticize others. $19 \%$ of Poles and $42 \%$ of Ukrainians neither agreed nor disagreed with the statement. Merely $27 \%$ of Poles and $25 \%$ of Ukrainians claim that their colleagues do not criticize others and their organizations are free from gossip and ambiguities. Men (50\%), more frequently than women, indicate the existence of criticism and gossip at their workplace. Women express similar views (42\%). Unfair comments and ambiguities emerge among $37 \%$ of women and merely $9 \%$ of men. $21 \%$ of women and $41 \%$ of men neither agree nor disagree with the statement (Figure 3 ).

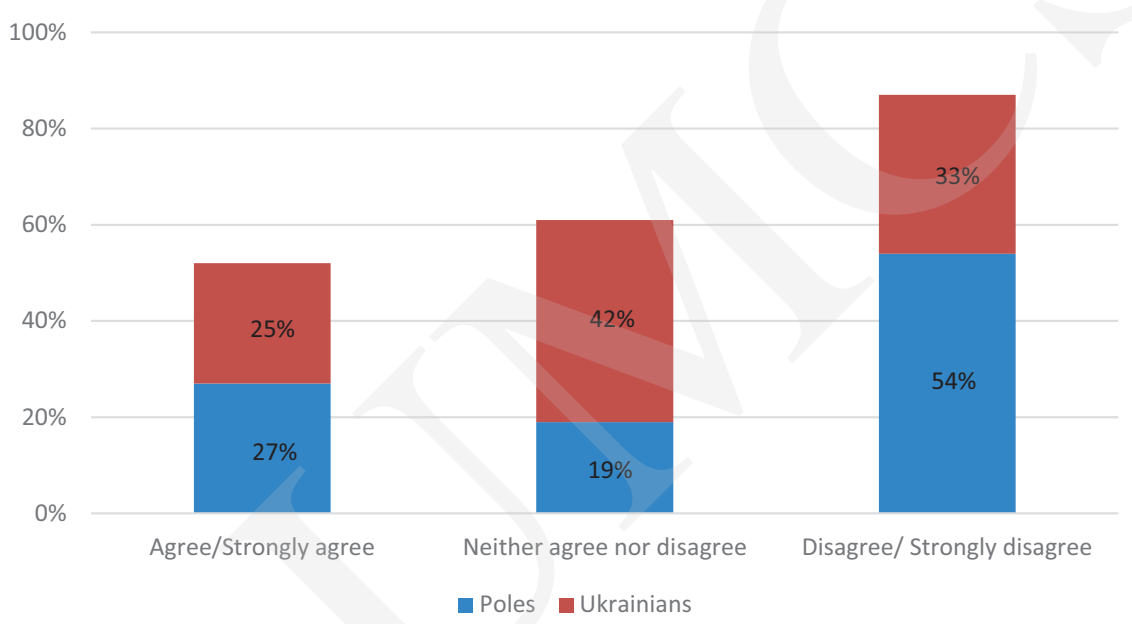

Source: Authors' own study.

Criticism and gossip are associated with several aspects of our lives. A premise can be made that these cannot be totally avoided. However, executives and those managing organizations ought to undertake actions in order to combat these. Organizational culture based upon suitable relations facilitates the execution of tasks which translates into achieved results.

The final statement associated with the organization's focus upon developing trustbased culture pertained to the organization informing employees on decisions made. Both Poles (50\%) and Ukrainians (53\%) expressed similar views stating the company's interest in informing employees on the reason behind a particular decision being made. $33 \%$ of Poles and $25 \%$ of Ukrainians disagreed - they believe that the organization does not share information on decisions it makes. $17 \%$ of Poles and $22 \%$ of Ukrainians neither agree nor disagree. As far as employees' sex is concerned, no significant disproportion was observed. $58 \%$ of women and $44 \%$ of men agree as to the existence of information flow concerning decisions made in their organizations. $25 \%$ of women and $34 \%$ of men disagreed. Merely $17 \%$ of women and $22 \%$ of men neither agreed nor disagreed. Informing employees on decisions made is a significant organizational process. By being informed, they feel that the management put trust in them. In addition, they are able to understand processes emerging in their workplaces more effectively.
Perception of Trust Levels in Organizations Based upon Opinions of Polish and Ukrainian Employees - Results of a Pilot Study

Figure 3. Results pertaining to statement No. 5 with regard to respondents' nationality: People avoid gossip and unfair criticism of others 


\section{IJSR}

\section{7}

Fiĝure 4.

Results of Polish respondents pertaining to opinions regarding trust. Division into the types of focus

\section{Figure 5.}

Results of Ukrainian respondents pertaining to opinions regarding trust. Division into the types of focus
To conclude the discussion of the above results, it is noteworthy that the trust in the surveyed aspects is high. Employees are aware of its existence. However, the majority of them possess no knowledge regarding how it impacts the operations of the organization they are members of. The trust of Polish employees does not differ significantly from the trust of respondents from Ukraine. This may result from the fact that most Ukrainian respondents have resided in Poland for 5 years.

Both Poles and Ukrainians indicate that companies' focus upon developing trustbased culture is assessed lower than the focus upon developing trust (Figures 4 and 5). When designing action plans and strategies, organizations ought to devote more attention to the culture of trust. Results of Polish respondents pertaining to their opinion on trust and the division into the specific types of focus are outlined in Figures 4 and 5.

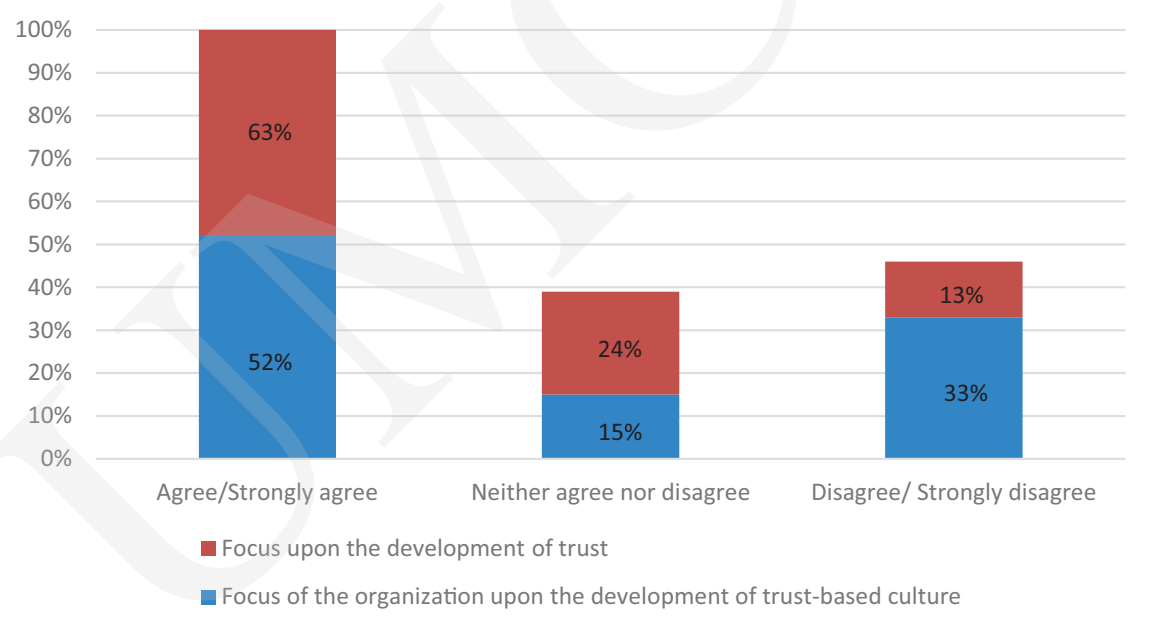

Source: Authors' own study.

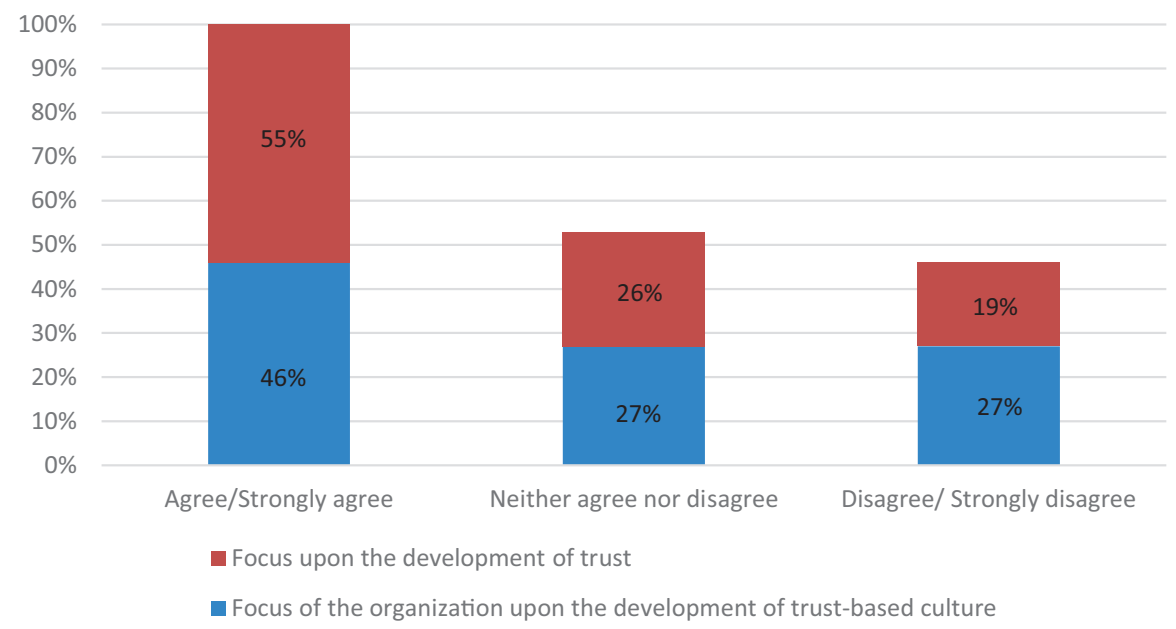

Source: Authors' own study, 


\section{Conclusions}

The present research results indicate that the level of trust of Polish employees is similar to that of the Ukrainian ones. This may result from the fact that the study encompassed young people whose attitudes were shaped in modern economy.

Although the results regarding the perception of the culture of trust are high, it can be observed that in the group of Ukrainian employees the results are lower. As a consequence, future studies ought to examine reasons behind the discrepancy. On the other hand, it can also be argued that Poles manifest less trust for new acquaintances than Ukrainians do.

All in all, this means that the results of the study are ambiguous and require further exploration.

Undeniably, trust constitutes a vital element of Polish organizations. Managers are becoming increasingly aware of its significance. This was acknowledged in the first area of the surveyed statements. In addition, employees also recognize that security and work atmosphere constitute factors exerting a strong impact upon the development of their organization. Managers highlight mutual relations, motivating their subordinates, and delegating tasks. However, they must be making a mistake because the majority of respondents do not trust their new coworkers. Polish organizations are also plagued with gossip and unfair criticism. Managers are also unable to tackle this issue. Management cadre devote too little attention to ensuring that the organizational culture is based upon trust. As a consequence, employees do not identify with their organizations and are not engaged in them. This, in turn, translates into decreased effectiveness in the long term. Polish companies readily employ Ukrainians because they undertake work frowned upon by Poles. In addition, Ukrainians are often better qualified, e.g. they know Russian language. If Ukrainians feel well in Poland, they will remain on our market. Therefore, it is vital to develop inclusive workplaces in Poland, ones which match the needs of employees and their situation.

Results regarding low trust level in the Polish society ought to be viewed as surprising and optimistic (Komunikat z badań..., 2018, pp. 1-5). This may suggest that respondents may not have been fully honest in their answers. Alternatively, it may suggest that the organizational culture facilitates the development of good relations and trust in the organization. It is noteworthy that this low level of trust may stimulate stagnation of economy. As far as the trust towards institutions is concerned, a study conducted by the Central Statistical Office of Poland in 2015 suggests that Poles trust emergency services, fire brigades, paramedics (Stodolak, 2017).

Due to changes emerging on the labor market, it seems appropriate to continue research in this area. The sample ought to be more representative and more diverse. It ought to include representatives of other nationalities working in Poland. This is important because trust is the basis for doing business successfully. Identifying factors determining the level of trust in the organization in the context of representatives of different countries may also be worthwhile.
Perception of Trust Levels in Organizations Based upon Opinions of Polish and Ukrainian Employees - Results of a Pilot Study 


\section{IJSR}

\section{References}

Andresen, M., Goldmann, P., and Volodina, A. (2017), "Do Overwhelmed Expatriates Intend to Leave? The Effects of Sensory Processing Sensitivity, Stress, and Social Capital on Expatriates' Turnover Intention", European Management Review, vol. 15, no. 3, pp. 315-328.

Archiwum Danych Społecznych (ADS), available at: www.ads.org.pl/opis-szczeg.php?id=15 (accessed: 7 April 2018).

Bjerke, B. (2004), Kultura a style przywództwa, zarządzanie w warunkach globalizacji, Oficyna Ekonomiczna, Kraków.

Czajkowska, M. (2008), „Kultura zaufania w organizacji. Istota - potrzeba - kształtowanie”, Annales. Etyka w życiu gospodarczym, vol. 11, no. 1, pp. 312.

Czapiński, J. (2008), „Kapitał ludzki i kapitał społeczny a dobrobyt materialny. Polski paradoks”, Zarzadzanie Publiczne, vol. 2, no. 4, pp . 5-28.

Fukuyama, F. (2003), „Kapitał społeczny”, in: L.E. Harrison, S.P. Huntington (eds.), Kultura ma znaczenie, Wydawnictwo Zysk i S-ka, Kraków.

Gross-Gołacka, E. (2017), „Koncepcja zarządzania różnorodnością i aspekt wzajemnego zaufania w organizacji źródłem innowacyjności i przewagi konkurencyjnej”, Przedsiębiorczość i Zarzadzanie, XVIII, vol. 10, no. 1, pp. 81-99, Wydawnictwo Społecznej Akademii Nauk, Łódź-Warszawa.

Grudzewski, W.M., Hejduk, I.K., Sankowska, A., and Wańtuchowicz, M. (2007), Zarządzanie zaufaniem $w$ organizacjach wirtualnych, Difin, Warszawa.

Horwat, K. (2017), Ukraińcy doceniaja pracę w Polsce, ale ponad połowa, gdyby mogła, wybrałaby Niemcy, available at: https://businessinsider.com.pl/twoje-pieniadze/praca/ukraincy-napolskim-rynku-pracy-raport-work-service/4hhfhy1 (accessed: 11 October 2018).

Hughes, M., Morgan, R.E., Ireland, R.D., and Hughes, P. (2014), "Social capital and learning advantages: A problem of absorptive capacity", Strategic Entrepreneurship Journal, vol. 8, no. 3, pp. 214-233.

Komunikat z badań. O nieufności i zaufaniu, (2018), Centrum Badania Opinii Społecznej, no. 35, Warszawa.

Królik, G. (2015), „Rola zaufania w relacjach interpersonalnych jako determinanta efektywności zespołu", Studia Ekonomiczne. Zeszyty Naukowe Uniwersytetu Ekonomicznego w Katowicach, no. 230, Wydawnictwo Uniwersytetu Ekonomicznego, Katowice.

Kuranchie, A., and Addo, H. (2017), "The link between social capital and learning outcomes: A literature review", Social Science and Humanities Journal, vol. 2, pp. 87-100.

Lewicka, D., and Krot, K. (2014), „Zaufanie organizacyjne jako czynnik kreujący proinnowacyjny klimat w organizacji”, Acta Universitatis Lodziensis, vol. 4, no. 305, pp. 47-58.

Lin, C.P., and Liu, M.L. (2017), "Examining the effects of corporate social responsibility and ethical leadership on turnover intention", Personnel Review, vol. 46, no. 3, pp. 526-550.

Liu, C.H.S. (2018), "Examining social capital, organizational learning and knowledge transfer in cultural and creative industries of practice", Tourism Management, vol. 64, pp. 258-270.

Mularska-Kucharek, M. (2011), ,Zaufanie jako fundament życia społecznego na przykładzie badań w województwie łódzkim", Studia Regionalne i Lokalne, vol. 2, no. 44, pp. 76-91.

Nowakowski, K. (2008), „Wymiary zaufania i problem zaufania negatywnego w Polsce”, Ruch Prawniczy, Ekonomiczny i Socjologiczny, vol. LXX, no. 1, pp. 213-233.

Ozyilmaz, A., Erdogan, B., and Karaeminogullari, A. (2018), "Trust in organization as a moderator of the relationship between self-efficacy and workplace outcomes: A social cognitive theorybased examination", Journal of Occupational and Organizational Psychology. The British Psychological Society, vol. 91, no. 1, pp. 181-204.

Paliszkiewicz, J. (2014), „Rola zaufania w zarządzaniu przedsiębiorstwami”, in: R. Knosala (ed.), Innowacje w zarzadzaniu i inżynierii produkcji, Oficyna Wydawnicza PTZP, Opole. 
Pawłowska, E. (2012), „Kapitał społeczny - diagnoza i pomiar”, Zeszyty Naukowe Politechniki Śląskiej, Politechnika Śląska Wydział Organizacji i Zarządzania, vol. 63a, no. 1891, pp. 88-89.

Peltokorpi, V., Allen, D.G., and Froese, F. (2015), "Organizational embeddedness, turnover intentions, and voluntary turnover: The moderating effects of employee demographic characteristics and value orientations", Journal of Organizational Behavior, vol. 36, no. 2, pp. 292-312.

Rakowska, A. (2018), "Diversity Management in Poland", in: A. Georgiadou, M.A. Gonzalez-Perez, M.R. Olivas-Luján (eds.), Diversity in Diversity Management. Special Issue: International Perspectives on Securing Human and Social Rights and Diversity Gains at Work in the Era of Global Economic Crisis and Austerity, Emerald Publishing, USA (in print).

Shore, L.M., Cleveland, J.N., and Sanchez, D. (2018), "Inclusive workplace: A review and model", Human Resource Management Review, vol. 28, no. 2, pp. 176-189.

Sierocińska, K. (2011), „Kapitał społeczny. Definiowanie, pomiar, typy”, Studia Ekonomiczne, vol. 1, no. 68, pp. 69-86, Wydawnictwo Instytutu Nauk Ekonomicznych Polskiej Akademii Nauk, Warszawa.

Stodolak, S. (2017), Dlaczego zaufanie w biznesie jest tak ważne? To ono tłumaczy różnice między PKB USA i Somalii. Dziennik Gazeta Prawna, available at: https://biznes.gazetaprawna.pl/ artykuly/1033490, dlaczego-zaufanie-w-biznesie-jest-tak-wazne-to-ono-tlumaczy-roznicemiedzy-pkb-usa-i-somalii.html,komentarze-najstarsze, 1 (accessed: 17 October 2018).

Sztompka, P. (2005), Socjologia. Analiza społeczeństwa, Wydawnictwo Znak, Kraków.

Tantardini, M., and Kroll, A. (2015), "The role of organizational social capital in performance management", Public Performance \& Management Review, vol. 39, no. 1, pp. 83-99.

Wróbel, P. (2010), „Rola i znaczenie kapitału społecznego w spółdzielniach socjalnych - analiza empiryczna wymiarów kapitału społecznego", Organizacja i Zarzadzanie: kwartalnik naukowy, vol. 1, no. 9, pp. 129-141. Wydawnictwo Politechniki Śląskiej, Gliwice.

Zarycki, T. (2008), „Dwa wymiary kapitału społecznego w kontekście polskim”, Pomorski Przeglad Gospodarczy, vol. 2, no. 37, Instytut Badań nad Gospodarką Rynkową.

\section{Perception of Trust Levels in Organizations Based upon Opinions of Polish and Ukrainian Employees - Results of a Pilot Study}

